Review

\title{
IMPACT OF OAT-BASED PRODUCTS ON HUMAN GASTROINTESTINAL TRACT
}

\author{
Aiga Staka ${ }^{1,2,3}$ \#, Edgars Bodnieks ${ }^{1,4}$, and Aldis Puḳitis ${ }^{1,3}$ \\ ${ }^{1}$ Gastroenterology, Hepatology and Nutrition Centre, Pauls Stradinš Clinical University Hospital, Pilsoṇu iela 13, \\ Rīga, LV-1002, LATVIA \\ ${ }^{2}$ Faculty of Chemistry, University of Latvia, Kr. Valdemāra iela 48, Rīga, LV-1013, LATVIA \\ ${ }^{3}$ Faculty of Medicine, University of Latvia, Raiṇa bulv. 19, Rīga, LV-1586, LATVIA \\ ${ }^{4}$ Rīga Stradinš̌ University, Faculty of Medicine, Dzirciema iela 16, Rīga, LV-1007, LATVIA \\ \# Corresponding author; kamene@ latnet.lv
}

Communicated by Valdis Pīrāgs

\begin{abstract}
Oat is rich in valuable nutrients. In comparison to other cereals, oat contains more total proteins, carbohydrate, fat, non-starch fibre, as well as unique antioxidants (one of them - avenanthramides), vitamins, and minerals. One of the most often studied components of oats is $\beta$-glucan a type of soluble dietary fibre located throughout the starch endosperm, but with highest concentration in the bran. Many studies have shown the beneficial health effects of oat $\beta$-glucan as a soluble dietary fibre. Until now, most of the studies on this nutrient have been conducted in the cardiovascular and diabetology field. This article aimed to review the literature on studies that investigated the effects of oat-based products on human gastrointestinal tract - gastrointestinal microflora, irritable bowel syndrome, inflammatory bowel disease as well as prevention/treatment of colorectal cancer. A literature search was conducted using PubMed database. More than 80 potential articles were identified, which were selected afterwards according to aims of our study. Studies done on human were preferred. A long-term dietary intake of oat-based products improves human intestinal microflora, could have benefits in irritable bowel syndrome, and probable effects were seen in patients with ulcerative colitis, but this remains to be proven. There are few studies regarding prevention/treatment of colorectal cancer and they do not show clear benefit nor provide recommendations.
\end{abstract}

Key words: Avena sativa, gastrointestinal microflora, irritable bowel syndrome, inflammatory bowel disease, colorectal cancer.

\section{INTRODUCTION}

The main role of our diet is to provide sufficient macro- and micronutrients to satisfy our needs for energy, growth, and development. During the past decades, the concept of "functional foods" has emerged, implying that some foods or its components are biologically active and can regulate various body functions, thereby being beneficial to health and reducing the risk of several diseases. Dietary fibre, an essential part of the human diet, consists of many substances of plant origin that are not digested in the human upper gastrointestinal tract, including polysaccharides such as cereal $\beta$-glucans, arabinoxylans and cellulose. Starch is not a part of dietary fibre, because it is hydrolysed by enzymes and absorbed in the small intestine. Dietary fibre regulates the rate of nutrient digestion and absorption, serves as a substrate for the gastrointestinal microflora of the gut and promotes laxation. The fibre affects gastrointestinal func- tion through properties including viscosity, water holding capacity, bulk, fermentability and binding of bile acids (Schneemann, 1987). An important feature of fibre is to reduce the rate of absorption of nutrients. One effect of fibre is conversion of carbohydrate components into a slow release form that requires less insulin and also increases the elimination of bile acids. Fibre also alters the colonic short-chain fatty acid profiles (Jenkins et al., 2001). Oats (Avena sativa) are cereals rich in dietary fibres, antioxidants, proteins and unsaturated fat, which makes them interesting as functional food ingredients (Sangwan et al., 2014). As the most common component of oats to be searched and studied are $\beta$-glucans. Therefore our literature review will be focused on oat $\beta$-glucan and its impact on the gastrointestinal tract. We searched for articles in the PubMed database describing studies with oat-based products and gastrointestinal tract. The search was limited to full-text English 
language articles, including review articles and meta-analyses. The studies were carried out mostly in humans, but some of the studies conducted in vitro and animals also included. Additional articles were identified by searching titles of references in relevant articles obtained from a database search.

\section{OAT $\beta$-GLUCAN. MOLECULAR STRUCTURE}

Oat consists of germ, endosperm and bran, which is rich in valuable nutrients. In comparison to other cereals, oat contains more total proteins, carbohydrate (may reach up to $75-80 \%)$, fat, non-starch fibre, as well as unique antioxidants (one of them - avenanthramides), vitamins, and minerals (Brand et al., 1996; Peterson et al., 1997). One of the most often studied components of oats is $\beta$-glucan $((1 \rightarrow 3),(1 \rightarrow 4)-\beta$-D-glucan $)$ - a type of soluble dietary fibre, which is located throughout the starch endosperm, but with the highest concentration in bran (Fig. 1). It contributes $3.6-5.1 \%$ of dry weight of the oat whole grain (Hampshire, 2004). Many studies have shown the beneficial health effects of oat $\beta$-glucan as a soluble dietary fibre. Until now, most of the relevant studies have been conducted in the cardiovascular and diabetology field. Consuming oats lowers the level of blood cholesterol and attenuates postprandial glucose response. A new meta-analysis published in the American Journal of Clinical Nutrition in 2014 shows that daily consumption of at least $3 \mathrm{~g}$ oat $\beta$-glucan reduces cholesterol levels. This effect was observed in lean, overweight and obese male and female adults, with and without type 2 diabetes, across 28 randomised controlled trials (Whitehead et al., 2014). The Food and Drug Administration (FDA) of

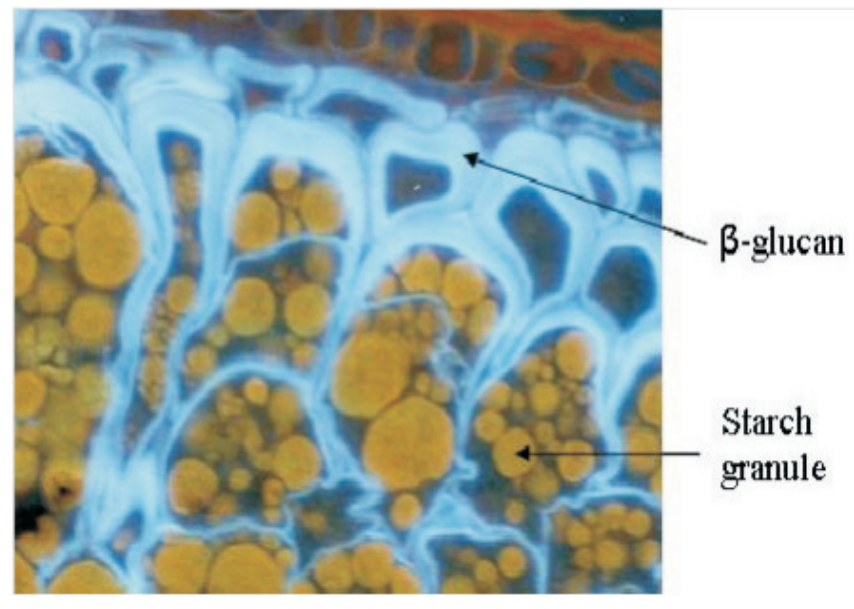

Fig. 1. Location of $\beta$-glucan in oat grain (www.oatsandhealth.org). the USA has accepted a health claim in which it is stated that a daily intake of $3 \mathrm{~g}$ of soluble oat $\beta$-glucan can lower the risk of coronary heart disease (FDA, 1997). The evidence presented indicates that the cholesterol-lowering effect of oat beta-glucan may depend on the increased viscosity in the small intestine, which reduces reabsorption of bile acids, increases the synthesis of bile acids from cholesterol, and reduces circulating (LDL) cholesterol concentrations. Oat $\beta$-glucan has a capacity to form highly viscous solutions. The hypocholesterolemic effect of $\beta$-glucan was related to the elevation of intestinal viscosity caused by $\beta$-glucan. Viscosity in the small intestine is determined by the concentration, molecular weight (MW) and solubility of oat beta-glucan (Wood et al., 1991). This is supported by a recent randomised clinical trial (RCT) that showed a reduced cholesterol lowering efficacy of oat $\beta$-glucan with low MW (210 kDa) compared to high MW (>2000 kDa) or medium MW $(530 \mathrm{kDa})$ oat $\beta$-glucan (Wolever et al., 2010). Oats also reduce the glucose and insuline responses. From molecular point of view, oat $\beta$-glucan is a linear polysaccharide that consists only of $\beta$-D-glucopyranosyl units (Fig. 2). These units are joined by either $(1 \rightarrow 3)$ - or $(1 \rightarrow 4)-\beta$-D-linkages, hence the name mixed-linkage (13),(14)- $\beta$-D- $\beta$-glucan. The distribution of the individual (13)- 22 and (14)-linkages is not random, nor is it regular. The (14)- $\beta$-links occur mostly in groups of two or three and are separated by a single $(1 \rightarrow 3)$-link, as first reported by Parrish et al. in 1960 and later on by others (Reese et al., 1962). The building blocks, 1.3-linked cellotriosyl and -cellotetraosyl units constitute over $90 \%$ of the molecule (Wood et al, 1994). The $(1 \rightarrow 3)$-link prevents close packing of the molecule and makes the molecule partly soluble in water, unlike cellulose, which is built entirely of $\beta$ - $(1 \rightarrow 4)$-linked D-glucanosyl units and is capable of close packing to crystalline structures. To summarise, cellulose is a $(1 \rightarrow 4)-\rightarrow$-D-glucan, where the $\beta$-glucoside bond makes the cellulose indigestable and insoluble. The mixed linked $(1 \rightarrow 3),(1 \rightarrow 4)-\rightarrow$-D-glucan is composed of $\beta(1 \rightarrow 4)$-linked glucose units with a single $\beta(1 \rightarrow 3)$-linked glucose every two or three units. It is the $(1 \rightarrow 3)$ linkages that make $\beta$-glucans soluble (Johansson, 2006). 20\% of oat and $46 \%$ of barley $\beta$-glucan is insoluble (Aaman et al., 1987).

The structure and properties of oat $\beta$-glucan vary between species and varieties of oats, and are also affected by the growing and storage conditions and processing of oat grain. In addition, the extraction and analysis methods may also contribute to the variations in the structure, molecular weight (Wang et al., 2014).

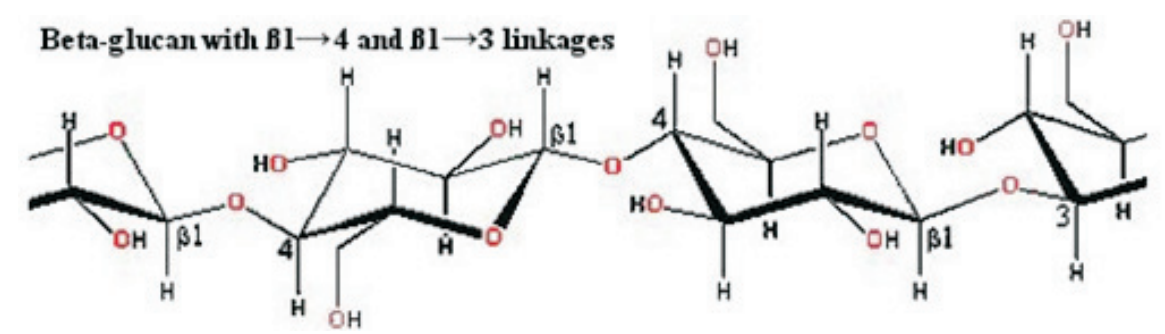

Fig. 2. Molecular structure of oat $\beta$-glucan. 
OATS AS PREBIOTICS, ITS INFLUENCE ON INTESTINAL MICROFLORA

In humans, intestinal microbiota plays an important role in the maintenance of host health by providing energy, nutrients, and immunological protection. The composition of the intestinal microbiota plays a significant role in human immunology, nutrition and pathological processes (Zoetendal et al., 2004). Describing the complexity and ecology of the intestinal microbiota is important for defining its effects on overall human health. Human intestinal microbiota undergoes maturation from birth to adulthood and is further altered with ageing. The major bacterial groups are Clostridium leptum, Clostridium coccoides, Bacteroidetes and Escherichia Coli. In healthy adults, $80 \%$ of the identified fecal microbiota can be classified into three dominant phyla: Bacteroidetes, Firmicutes and Actinobacteria. In general terms, the Firmicutes to Bacteroidetes ratio is regarded to be of significant relevance in human gut microbiota composition. Although the intestinal microbiota is relatively stable throughout adult life, recent studies indicated that modifications occur in the composition in elderly individuals. For example, a reduction in the numbers of Bifidobacteria and Bacteroides has been observed, accompanied also by a decrease of Lactobacilli. The major functions attributed to the microbiota present in the gut begin to manifest at the end of the second year of life and comprise: i) nutrients absorption and food fermentation; ii) stimulation of the host immune system, and iii) barrier effects against pathogens. The majority of microbiota are anaerobic, and although more than 50 bacterial phyla have been described, only four predominate in the mammalian GI tract: Bacteroidetes, Firmicutes, Actinobacteria, and Proteobacteria. Of these, Bacteroidetes and Firmicutes account for more than 90\% of the bacteria in the human GI tract (Eckburg et al., 2005; Mariat et al., 2009). It is estimated that approximately 4000 bacterial species reside in human GI tracts, comprising as many as $10^{14}$ bacterial cells, a number 10 times greater than the number of cells in the human body. Per gram of content, there is a marked and progressive distal increase in the number of bacteria: $10^{1}$ in the stomach, $10^{3}$ in the duodenum, $10^{4}$ in the jejunum, $10^{7}$ in the ileum, and $10^{12}$ in the colon (Sekirov et al., 2010). Probiotics are live microorganisms, which when administered in adequate amount, confer a health benefit on the host. Prebiotics are non-digestible food ingredients that beneficially affect the host by selectively stimulating the growth or activity of one or a limited number of bacteria in the colon and thus improve host health (Gibson et al., 1995).

Oats, besides a high content of $\beta$-glucans, also contain arabinoxylans and cellulose, which are mainly insoluble fibre. The fibres are not digested in the small intestine, but the soluble $\beta$-glucan is believed to increase the viscosity of the food bolus, leading to a slower gastric emptying, enhanced gut fill and slower absorption of nutrients. All these mentioned factors contribute to stimulation of growth of human microflora. In a study from Romania and Italy, oat bran extract added to milk selectively promoted the number of probiotic bacteria (Lactobacillus rhamnosus, Lactobacillus paracasei, and also their combination SYNBIO) in milk and maintained overall microbial counts over a 28-day storage period with respect to controls (whole milk without substrates). Therefore, a new synbiotic product (combination of prebiotics and probiotics) was developed. The probiotic strains were recovered from fecal samples from 40 volunteers fed for 4-week period (Coman et al., 2013). Oats have been shown to increase the proportion of short chain fatty acid (SCFA) butyrate, which has regulatory functions in cell proliferation and differentiation. $\beta$-glucan, however, leads mainly to the production of another SCFA - propionate, which is suggested as one of the mechanisms for the cholesterol lowering effects of oats and other $\beta$-glucan-containing products (Wolever et al., 1991). Similar results were obtained in a study in Greece (Mantzouridou et al., 2013). A study in the United Kingdom (Kedia et al., 2009) showed that oat bran fraction added to human fecal cultures decreased culturable anaerobes and clostridia and promoted increase in bifidobacteria and lactobacilli populations.

Fermentable dietary fibre is the most important source for formation of SCFA in the large intestine. Beta-glucans, pectin and resistant starch are fermented to $70-100 \%$, whereas, for example, cellulose is usually not fermented at all. The major SCFAs produced after fermentation of dietary fibres are acetate, propionate and butyrate. Certain colonic bacteria generate energy from these fermentation products. The properties of the microflora and the composition of the substrate (dietary fibre) are important factors both for the total and individual SCFA formed. The SCFAs are physiologically active in different ways. Acetate is readily taken up from the intestine and transported to the liver, where it can serve as a substrate for cholesterol biosynthesis. Butyrate serves as a fuel for epithelial cells and can also regulate cell proliferation and differentiation. Recently, butyrate was suggested to have influence on lipid metabolism by regulation of intestinal fat absorption. Propionate may contribute to hypocholesterolemic action by either inhibiting HMG-CoA reductase or by preventing utilisation of acetate for cholesterol synthesis. A substantial amount of bacteria is present in the ileum, but the vast majority of bacteria exist in the proximal large bowel, where fermentation also takes place. It is in the caecum and ascending colon that the SCFA production reaches its highest concentration in humans. At both the colonic and systemic levels, fermentation and especially SCFA production play an integral role. Colonic epithelial cells preferentially use butyrate as an energy source, even when competing substrates such as glucose and glutamine are available. Butyrate is considered a key nutrient determining the metabolic activity and growth of colonocytes and may function as a primary protective factor against colonic disorders, although data on this topic are conflicting (Andersson, 2009). SCFAs are water-soluble and are absorbed into the blood stream. The brain, muscles, and tissues metabolise acetate systemically, whereas propionate is cleared by the liver and may lower the hepatic production of cholesterol by interfering with its synthesis. 
Transport to and further metabolism of SCFAs in the liver, muscle, or other peripheral tissues is thought to contribute about $7-8 \%$ of host daily energy requirements (Cummings et al., 1991). Fermentation and SCFA production also inhibit the growth of pathogenic organisms by reducing luminal and fecal $\mathrm{pH}$. Low $\mathrm{pH}$ reduces peptide degradation and the resultant formation of toxic compounds, such as ammonia, amines, and phenolic compounds, and decreases the activity of undesirable bacterial enzymes (Thornton, 1981; Smith et al, 1996). The gastrointestinal microbiota plays important roles in health and disease, but the diversity of the microbiota is poorly defined and yet far from completely characterised. In another study from Ireland and UK, although $\beta$-glucans displayed no apparent prebiotic potential, it significantly modulated the microbial communities and the resulting SCFA (51:32:17; acetate : propionate : butyrate) profile. Acetate was the most prevalent SCFA in all treatments; accounting for $44 \%$ of the SCFA produced with the $\beta$-glucan treatments; $67.3 \%$ in the no treatment control, and $63.3 \%$ with inulin, at $48 \mathrm{~h}$. However, fermentation of $\beta$-glucan resulted in higher total amounts and proportions of propionate; ranging from $30 \%$ with $150-\mathrm{kDa}$ oat $\beta$-glucan treatment, to $37.1 \%$ with $172-\mathrm{kDa}$ barley-glucan, at $48 \mathrm{~h}$. This study revealed that the main group of human faecal microbial communities involved in $\beta$-glucan fermentation was the $C$. histolyticum group, and to a lesser extent Clostridia cluster IX and the Bacteroides-Prevotella and Atopobium groups (Hughes et al., 2008).

\section{ß-GLUCANS AND IRRITABLE BOWEL SYNDROME (IBS)}

One of the most common gastrointestinal diseases of the world is IBS, affecting $8-22 \%$ and accounting for $20-50 \%$ of referrals to gastroenterology clinics. It is characterised by abdominal pain, excessive flatus, variable bowel habit and abdominal bloating for which there is no evidence of detectable organic disease (Madden et al., 2002). Although the pathogenesis is still not fully understood, one of the popular theories is altered gastrointestinal microflora, as some bacteria are more prone to gas production than others. In a study, 60 IBS patients were randomised in two groups: for a period of four weeks one group received rose-hip drink containing Lactobacillus plantarum and oat flour, and the other group were given plain rose-hip drink. The results of the study showed that patients receiving Lactobacillus plantarum and oat flour drink had decreased pain and flatulence compared with the placebo group. Therefore, probiotic therapy with oat fibre (as prebiotics) could be one of the treatment options in patients with IBS. Although fibre content of the test solution was minimal and it is unlikely that the fibre content could have had any effect, this type of probiotic therapy warrants further study in IBS patients (Nobaek et al., 2000). In a study from Italy, 50 patients with IBS received pills made from beta-glucans and inositol $\left(\right.$ Biointol $^{\mathrm{TM}}$ ) for four weeks. Patients who were treated with Biointol significantly decreased abdominal bloating, flatulence and abdominal pain, with a slightly increasing ur- gency of bowel movements, compared with the placebo group (Ciacci, 2011). Other studies showed similar decrease of gastrointestinal symptoms after probiotic therapy, but without oat-based product addition (Guyonnet et al., 2007; Kajander et al., 2008). These studies stressed the possible role of altered gastrointestinal microflora in pathogenesis of IBS as well as role of prebiotics, including oat $\beta$-glucans and probiotics in the treatment of IBS.

\section{ß-GLUCANS AND INFLAMMATORY BOWEL DIS- EASE (IBD)}

IBD are two related chronic inflammatory disorders characterised by acute flares followed by remission: ulcerative colitis (UC) and Crohn's disease (CD). UC affects the inner lining of the colon, which becomes inflamed and develops ulcers. UC generally involves the distal part of the colon, but may progress proximally to pancolitis. CD tends to involve the entire bowel wall and commonly affects the terminal ileum and parts of the colon, but may affect any part of the gastrointestinal tract. A major complication of $\mathrm{CD}$, affecting many $\mathrm{CD}$ patients is the formation of fistulas and stenosis (Feldman et al., 2010). Furthermore, UC and CD may be considered systemic disorders, as around $6-47 \%$ of IBD patients experience extraintestinal complications. The organs most commonly involved include skin, eyes, joints, biliary tract and lungs (Rothfuss et al., 2006). The incidence of IBD varies considerably worldwide with incidence rates between $0.5-24.5 / 105$ and $0.1-16 / 105$ inhabitants for UC and CD. The highest rates are reported in Northern and Western Europe as well as North America (Lakatos, 2006). The etiology and pathophysiology of both UC and CD is complex. Accumulating evidence suggests that an inappropriate immune response to non-pathogenic microbes of the intestine and other luminal antigens plays a critical role in the initiation and pathogenesis of IBD. The increased IBD incidence over the past decades, particularly in developing countries, suggests that environmental factors are implicated in IBD development, although there is evidence about genetic susceptibility as well (Feldman el al., 2010).

IBD is associated with overexpression of pro-inflammatory cytokines, including TNF- $\alpha$, interferon (IFN), IL-1 and IL-6. CD and UC have been considered to be Th1- and Th2-driven diseases, respectively, although the picture now appears more complex. Th17 cells, a distinct subset of CD4+ Th cells characterised by abundant IL-17 production, are associated with intestinal inflammation and tissue pathology and have attracted considerable attention recently. A cytokine IL-23, is central in promoting Th17 cells. The above mentioned cytokines and their producers may prove to be attractive therapeutic targets (Gálvez, 2014; Maloy et al., 2008). IBD is routinely treated with antibiotics, immunosuppressive and anti-inflammatory drugs. Promising antibody-based therapeutics that block key cytokines and interfere with $\mathrm{T}$ cell activation and migration of inflammatory cells have emerged as potent alternative therapies for IBD. Although these strategies may prove effective, available therapeutics are associated with considerable ad- 
verse reactions, including opportunistic infections. Patients with severe IBD, refractory to medical treatment or with neoplastic transformation, require surgery. For selected cases (proctocolectomy in UC and ileocolonic resection in Crohn's disease), minimally invasive surgery can be the treatment option with speeding recovery, reducing costs and decreasing morbidity (Polle et al., 2007). Surgery continues to have an important role in IBD treatment, as $30-40 \%$ of UC patients and $70 \%$ of CD patients require surgical intervention at some point. Total colectomy, the only cure for $\mathrm{UC}$, is indicated in approximately $25 \%$ of UC patients (Surlin et al., 2012). Notably, as many as $40-60 \%$ of IBD patients respond poorly to current standard therapy, indicating a considerable need for new, more effective and safe therapies (Katz, 2007).

Regarding ethiopathology of IBD, which is still under investigation, several studies have reported that IBD is associated with impairment in SCFA production, mainly acetate, propionate, and butyrate. They are produced in the large bowel by anaerobic bacterial fermentation of undigested dietary carbohydrates and fibre polysaccharides, with butyrate being considered as the major fuel source for colonocytes. These SCFAs have been proposed to play a key role in the maintenance of colonic homeostasis. Therefore, it is reasonable to consider therapeutic approaches that increase colonic SCFA production, as can be achieved by administration of dietary fibre to IBD patients, including oats. There is mounting evidence that carboxylic acids (CAs) formed by colonic fermentation of indigestible carbohydrates have positive health effects. In this context, butyric acid and, to some extent, propionic acid have mainly been emphasised. These acids are important energy sources for the colonocytes and may thus improve the condition of the colonic mucosa and, in consequence, decrease the risk of mucosal lesions. Especially butyric acid has been suggested to play a role in the prevention and treatment of colonic diseases, such as ulcerative colitis and colon cancer, and to some extent Crohn's disease. Carboxylic acids (CAs), especially butyric acid, have been suggested to counteract colonic diseases, such as ulcerative colitis and colon cancer. Unfortunately, there is quite limited documentation of efficacy of dietary fibre in properly designed trials (Galvez, 2005). In the 1990s, a popular study direction was SCFA topical treatment in distal ulcerative colitis, most of which showed positive results (Breuer et al., 1991; Steinhart et al., 1996). Comparing butyrate, which mostly has been investigated, with two other SCFA, namely acetate and propionate, which have less well-documented effect on inflammation, a study in Sweden proved that propionate and butyrate were equipotent, whereas acetate was less effective, but still useful in the treatment of IBD (Tedelind et al., 2007). A study from Italy showed good results with $4 \mathrm{~g}$ /day butyrate as enteric coated tablets for 8 -week treatment of mild-moderate ileocolonic Crohn's disease. This therapy was safe and well tolerated and $53 \%$ of patients achieved remission (Di Sabatino, 2005).
Most studies on colonic microbiota have focused on fecal material, although increasing evidence suggests that the epithelial surface is also colonised by large and diverse bacterial communities, which are structurally distinct from those that live in gut lumen. These mucal communities can change markedly in inflammatory conditions, such as inflammatory bowel disease. Importantly, the composition of these mucosal communities in humans can be manipulated through the use of prebiotics (Macfarlane et al., 2004).

\section{ß-GLUCANS AND COLORECTAL CANCER}

Non-prescriptional use of medicinal herbals among cancer patients has been known around the world. Some chemotherapeutic drugs, like vincristine and taxol, are purified from herbs. $\beta$-glucans are believed to have various imunomodulatory properties. Studies in vitro and in vivo revealed that the immunostimulating activity of $\beta$-glucan depends on structure, molecular weight and number of branches. Based on in vitro studies, $\beta$-glucans act on several immune receptors, including Dectin-1, which is one of better known and studied. There are some limitations of those studies, for example, there are no available $\beta$-glucan control standards with specific molecular weight and branches. Most of the $\beta$-glucans used in research are based on extracts rather purified $\beta$-glucans, and therefore it is not possible to exclude confounding factors. The exact immunological action and signalling pathway are still unclear and have to be further defined (Chan et al., 2009). $\beta$-glucans from various sources possess different characteristics and $\beta$-glucans with additional branching have the highest immunostimulating activity (Freimund et al., 2003). Therefore, until now most studies in oncology have used $\beta$-glucans isolated from yeasts. Searching through PubMed, there are few studies regarding use of oat $\beta$-glucans in prevention or treatment of colorectal cancer. One of them, conducted on 25 healthy subjects in Sweden, suggested that dietary supplementation with oat bran (40 g $\beta$-glucan enriched) per day can serve as an excellent source of carboxyl acids. After 8 and 12 weeks, the fecal concentrations of acetic, propionic and isobutyric acid were higher compared with values at entry. Oat bran may therefore have a preventive potential in regard to colonic diseases (Nilsson et al., 2007). Although the studies until now performed have shown positive results from $\beta$-glucan and its metabolites $\mathrm{CA}$, on intestinal epithelium, there is one study from Canada, Ontario, with opposite results. The aim of that study was to determine whether $\beta$-glucan from oats can shield intestine epithelial cells from oxidative cell injury. The study was done on rat small intestine epithelial cells, which were cultured with or without medium viscosity oat $\beta$-glucan at various concentrations and treated with serial diluted $\mathrm{H}_{2} \mathrm{O}_{2}$. The activity of inflammatory substances (superoxide dismutase activity, expression of TNF- $\alpha$, activity of caspase-3) was increased by $\mathrm{H}_{2} \mathrm{O}_{2}$ only under the higher concentration of $\beta$-glucan. Therefore, the study revealed that low levels of $\beta$-glucan do not appear to protect small intestine epithelial cells against $\mathrm{H}_{2} \mathrm{O}_{2}$ induced oxidative injury, while applica- 
tion of higher doses of this soluble fibre promoted oxidative cell injury induced by $\mathrm{H}_{2} \mathrm{O}_{2}$. This study expands the current understanding regarding dietary soluble fibre and intestine health and disease, suggesting that oat $\beta$-glucan creates a negative challenge to intestinal mucosa cells and may act in synergy with oxidative cell injury induced by reactive oxygen species. However, as this study was conducted on animals, further studies in humans are necessary to prove or reject this unexpected result.

\section{ACKNOWLEDGMENTS}

This research received financial support from the European Social Fund project No. 2013/0072/1DP/1.1.1.2.0/13/APIA/ VIAA/032.

\section{REFERENCES}

Aaman, P., Graham, H. (1987). Analysis of total and insoluble mixed-linked $\beta$-D-glucans in barley and oats. J. Agric. Food Chem., 35 (5), 707-709.

Andersson, K. (2009). Molecular Weight of Beta Glucans, Bioactivity. Doctoral dissertation, Lund University, Faculty of Medicine, Sweden. Media-tryck, Lund. 67 pp.

Brand, T. S., Van der Merwe, J. P. (1996). Naked oats (Avena nuda) as a substitute for maize in diets for weaning and grower-finsher pigs. Anim. Feed Sci. Technol., 57, 139-141.

Breuer, R. I., Buto, S. K., Christ, M. L., Bean, J., Vernia, P., Paoluzi, P., Di Paolo, M. C., Caprilli, R. (1991). Rectal irrigation with short-chain fatty acids for distal ulcerative colitis. Preliminary report. Dig. Dis. Sci., 36 (2), 185-187.

Cha, M. C., Purslow, P. P. (2014). Soluble fiber beta-glucan from oats at higher concentrations promotes hydrogen peroxide-induced cytotoxicity in small intestine epithelial cells. Advances Life Sci. Health, 1 (2), 36-46.

Chan, G. C. F., Chan, W. K., Sze, D. M. Y. (2009). The effects of $\beta$-glucan on immune and cancer cells. J. Hemat. Oncol., 2, 25.

Ciacci, C., Franceschi, F., Purchiaroni, F., Capone, P., Buccelletti, F., Iacomini, P., Ranaudo, A., Andreozzi, P., Tondi, P., Gentiloni Siveri, N., Gasbarrini, A., Gasbarrini, G. (2011). Effect of ß-glucan, inositol and digestive enzymes in GI symptoms of patients with IBS. Eur. Rev. Med. Pharmacol. Serv., 15, 637-643.

Coman, M. M., Verdenelli, M. C., Cecchini, C., Silvi S., Vasile, A., Bahrim, G. E., Orpianesi, C., Cresci, A. (2013). Effect of buckwheat flour and oat bran on growth and cell viability of the probiotic strains Lactobacillus rhamnosus IMC 501®, Lactobacillus paracasei IMC 502® and their combination SYNBIO®, in synbiotic fermented milk. Int. J. Food Microbiol., 167 (2), 261-268.

Cummings, J. H., Macfarlane, G. T. (1991). The control and consequences of bacterial fermentation in the human colon. J. Appl. Bacteriol., 70, 443-459.

Di Sabatino, A., Morera, R., Ciccocioppo, R., Cazzola, P., Gotti, S., Tinozzi, F. P., Tinozzi, S, Corazza, G. R. (2005). Oral butyrate for mildly to moderately active Crohn's disease. Aliment. Pharmacol. Ther., 22, 789-794.

Eckburg, P. B., Bik, E. M., Berstein, C. N., Purdom, E., Dethlefsen, L., Sargent, M., Gill, S. R., Nelson. K. E., Relman, D. A. (2005). Diversity of the human intestinal microbial flora. Science, 308, 1635-1638.

Anonoymous (1997). Food labeling: Health claims; oats and coronary heart disease; final rule. Federal Register (Food and Drug Administration, USA), 62 (15), 3583-3601.

Feldman, M., Friedman, L. S., Brandt, L. J. (eds.) (2010). Sleisenger and Fordtran's Gastrointestinal and Liver Disease-2 Volume Set. $9^{\text {th }}$ edn. Saunders Elsevier, Philadelphia. 2480 pp.
Freimund, S., Sauter, M., Kapelli, O., Dutler, H. (2003). A new nondegradingisolation process for 1.3- $\beta$-glucan of high purity from baker's yeast saccharomyces cerevisae. Carbohyd. Polym., 54, 159-171.

Galvez, J., Rodríguez-Cabezas, M. E., Zarzuelo, A. (2005). Effects of dietary fiber on inflammatory bowel disease. Mol. Nutr. Food Res., 49 (6), 601-608.

Gálvez, J. (2014). Role of Th17 Cells in the Pathogenesis of IBD. Int. Schol. Res. Notices Inflamm. Article ID 928461, 14 pp. htpp:/dx.doi.org.10.1155.2014/928461 (accessed 15 June 2015).

Gibson, G. R, Roberfroid, M. B. (1995). Dietary modulation of the human microbiota: Introducing the concept of prebiotics. J. Nutr., 125, 1401-1412.

Guyonnet, D., Chassany, O., Ducrotte, P., Picard, C., Mouret, M., Mercier, C. H., Matuchansky, C. (2007). Effect of a fermented milk containing Bifidobacterium animalis DN-173 010 on the health-related quality of life and symptoms in irritable bowel syndrome in adults in primary care: A multicentre, randomized, double-blind, controlled trial. Aliment Pharmacol. Ther., 26, 475-486.

Hampshire, J. (2004). Variation in the content of nutrients in oats and its relevance for the production of cereal products. Proceedings of the $7^{\text {th }}$ International Oat Conference, Helsinki, Finland. Agrifood Res. Rep., 51, 126.

Hughes, S. A, Shewry, P. R., Gibson, G. R, McCleary, Rastall, R. A. (2008). In vitro fermentation of oat and barley derived $\beta$-glucans by human faecal microbiota. FEMS (Federation of European Microbiological Societies) Microbiol. Ecol., 6 (3), 482-493.

Jenkins, D. J., Kendall, C. W., Popovich, D. G., Vidgen, E., Mehling, C. C., Vuksan, V., Ransom, T. P., Rao, A. V., Rosenberg-Zand, R., Tariq, N., Corey, P., Jones, P. J., Raeini, M., Story, J. A., Furumoto, E. J., Illingworth, D. R., Pappu, A. S., Connelly, P. W. (2001). Effect of a very-high-fiber vegetable, fruit, and nut diet on serum lipids and colonic function. Metabolism, 50 (4), 494-503.

Johansson, L. (2006). Structural analyses of $(1 \rightarrow 3),(1 \rightarrow 4)-\beta-D$-glucan of oats and barley. Published doctoral dissertation. University of Helsinki, Department of Applied Chemistry and Microbiology, General Chemistry Division, Helsinki.

Kajander, K., Myllyluoma, E., Rajilić-Stojanović, M., Kyrönpalo, S., Rasmussen, M., Järvenpää, S., Zoetendal, E. G., de Vos, W. M., Vapaatalo, H., Korpela, R. (2008). Clinical trial: Multispecies probiotic supplementation alleviates the symptoms of irritable bowel syndrome and stabilizes intestinal microbiota. Aliment Pharmacol. Ther., 27 (1), 48-57.

Katz, S. (2007). "Mind the Gap": An unmet need for new therapy in IBD. J. Clin. Gastroenterol., 41, 799-809.

Kedia, G., Váquez, J. A., Pandiella, S. S. (2009). In vitro fermantation of oat bran obtained by debranning with a mixed culture of human faecal bacteria. Curr. Microbiol., 4, 338-342.

Lakatos, P. L. (2006). Recent trends in the epidemiology of inflammatory bowel diseases: Up or down? World J. Gastroenterol., 12, 6102-6108.

Macfarlane, S., Furrie, E., Cummings, J. H., Macfarlane, G. T. (2004). Chemotaxonomic analysis of bacterial populations colonizing the rectal mucosa in patients in ulcerative colitis. Clin. Infect. Dis., 38, 1690-1699.

Madden, J. A., Hunter, J. O. (2002). A review of the role of the gut microflora in irritable bowel syndrome and the effects of probiotics. Brit. J. Nutr., 88 Suppl 1, 67-72.

Maloy, K. J, Kullberg, M. C. (2008). Il-23 and Th17 cytokines in intestinal homeostasis. Mucosal Immunol., 1 (5), 339-349.

Mantzouridou, F., Karousioti, A., Kiosseoglou, V. (2013). Formulation optimisation of a potentially prebiotic low-in-oil oat-based salad dressing to improve Lactobacillus paracasei subsp.paracasei survival and physicochemical characteristics. Food Sci. Technol., 53 (2) 560-568.

Mariat, D., Firmesse, O., Levenez, F., Guimarćes, V. D., Sokol, H., Doré, J., Corthier, G., Furet, J. P. (2009). The Firmicutes/Bacteroidetes ratio of the human microbiota changes with age. BMC Microbiol., 9, 123. 
Nilsson, U., Johansson, M., Nilsson, Å., Björck, I., Nyman, M. (2008). Dietary supplementation with $\beta$-glucan enriched oat bran increases faecal concentration of carboxylic acids in healthy subjects. Eur. J. Clin. Nutr., 62, 978-984.

Nobaek, S., Johansson, M. L., Molin. G., Ahrné, S., Jeppsson, B. (2000). Alteration of intestinal microflora is associated with reduction in abdominal bloating and pain in patients with irritable bowel syndrome. Amer. J. Gastroenterol., 95 (5), 1231-12388.

Peterson, D. M, Wood, D. F. (1997). Composition and structure of high-oil oat. J. Cereal Sci., 26 (1), 121-128.

Polle, S. W., Bemelman, W. A. (2007). Surgery insight: Minimally invasive surgery for IBD. Nat. Clin. Pract. Gastroenterol. Hepatol., 4, 324-335.

Reese, E. T., Parrish, F. W., Mandels, M. (1962). $\beta$-D-1,6-glucanases in fungi. Can. J. Microbiol., 8 (3), 327-334.

Rothfuss, K. S., Stange, E. F., Herrlinger, K. R. (2006). Extraintestinal manifestations and complications in inflammatory bowel disease. World J. Gastroenterol., 12 (30), 4819-4831.

Sangwan, S., Singh, S., Tomar, S. K. (2014). Nutritional and functional properties of oats: An update. J. Innovative Biol., 1 (1), 3-14.

Scheemann, B. O. (1987). Dietary fiber and gastrointestinal function. Nutr. Rev., 45 (5), 129-132.

Sekirov, I., Russell, S. L., Antunes, L. C., Finlay, B. B. (2010). Gut microbiota in health and disease. Physiol. Rev., 90 (3), 859-904.

Smith, E. A., Macfarlane, G. T. (1996). Enumeration of human colonic bacteria producing phenolic and indolic compounds: Effects of $\mathrm{pH}$, carbohydrate availability and retention time on dissimilatory aromatic amino acid metabolism. J. Appl. Bacteriol., 81, 288-302.

Steinhart, A. H., Hiruki, T., Brzezinski, A, Baker, J. P. (1996). Treatment of left-sided ulcerative colitis with butyrate enemasa controlled trial. Aliment Pharmacol. Ther., 10 (5), 729-736.

Surlin, V., Copaescu, C., Saftoiu, A. (2012). An update to surgical management of inflammatory bowel diseases. DOI: http:/dx.doi.org/10.5772/53057. http://cdn.intechopen.com/pdfs-wm/ 41223.pdf (accessed 12 April 2015).

Tedelind, S., Westberg, F., Kjerrulf, M., Vidal, A. (2007). Anti-inflammatory properties of the short-chain fatty acids acetate and propionate: A study with relevance to inflammatory bowel disease. World J. Gastroenterol., 13, 2826-2832.

Thornton, J. R. (1981). High colonic pH promotes colorectal cancer. Lancet, 1, 1699-1728.

Wang, Q., Ellis, P. R. (2014). Oat $\beta$-glucan: Physico-chemical characteristics in relation to its blood-glucose and cholesterol-lowering properties. Brit. J. Nutr., 112 Suppl 2, S4-S13.

Whitehead, A., Beck, E. J., Tosh, S. M, Wolever, T. M. S. (2014). Cholesterol-lowering effects of oat $\beta$-glucan: A meta-analysis of randomized controlled trials. Amer. J. Clin. Nutr., 100 (6), 1413-1421.

Wood, P. J., Weisz, J., Blackwell, B. A. (1994). Structural studies of $(1 \rightarrow 3)$ $(1 \rightarrow 4)$ - $\beta$-D-glucans by $13 \mathrm{C}$-nuclear magnetic resonance spectroscopy and by rapid analysis of cellulose-like regions using high-performance anion-exchangechromatography of oligosaccharides released by lichenase. Cereal Chem., 35, 301-307.

Wood, P. J., Weisz, J., Mahn, W. (1991). Molecular characterization of cereal, $\beta$-glucans. II. size-exclusion chromatography for comparison of molecular weight. Cereal Chem., 68 (5), 530-536.

Wolever, T. M., Tosh, S. M., Gibbs, A. L., Brand-Miller, J., Duncan, A. M., Hart, V., Lamarche, B., Thomson, B. A., Duss, R., Wood, P. J. (2010). Physicochemical properties of oat $\beta$-glucan influence its ability to reduce serum LDL cholesterol in humans: A randomized clinical trial. Amer. J. Clin. Nutr., 92 (4), 723-32.

Zoetendal, E. G., Collier, C. T., Koike, S., Mackie, R. I, Gaskins, H. R. (2004). Molecular ecological analysis of the gastrointestinal microbiota: A review. J. Nutr., 134, 465-472.

Wolever, T. M., Spadafora, P., Eshuis, H. (1991). Interaction between colonic propionate and acetate in humans. Amer. J. Clin. Nutr., 53 (3), 681-687.

Received 14 April 2015

\section{AUZU PRODUKTU IETEKME UZ CILVĒKA GASTROINTESTINĀLO TRAKTU}

Auzās ir daudz vērtīgu barības vielu. Salīdzinot ar citiem graudaugiem, tās satur vairāk kopējo olbaltumvielu, og̣̣hidrātu, tauku, ne-cietes šiedrvielas, dažus unikālus antioksidantus (viens no tiem - avenantramīdi), vitamīnus un minerālvielas. Viena no visbiežāk pētītajām auzu sastāvdaḷām ir $\beta$-glikāni. Tā ir šḳ̄stoša šḳiedrviela, kas atrodas auzu graudā, visvairāk — grauda ārējā daḷā. Daudzos pētījumos ir pierādīta $\beta$-glikānu labvēlīgā ietekme uz cilvēka veselību. Visvairāk pētījumu ar $\beta$-glikāniem ir veikti kardioloǵijā un diabetoloǵijā. Šis apskatraksts ir veltīts pētījumiem par auzu $\beta$-glikānu ietekmi uz cilvēka gastrointestinālo traktu: gastrintestinālo mikrofloru, kairinātu zarnu sindromu, iekaisīgām zarnu slimībām un kolorektāla vēža profilaksi/ārstēšanu. Literatūras apskatā izmantoti pētījumi no PubMed datu bāzes. Tika atlasīti vairāk kā 80 pētījumi un apskatraksti, kas veltīti šai tēmai, no kuriem tālāk pārsvarā analizēti pētījumi, kas veikti ar cilvēkiem. Ilgstoša auzu produktu lietošana uzturā labvēlīgi ietekmē gastrointestinālo mikrofloru. Iespējama labvēlīga ietekme uz slimības gaitu novērota kairinātu zarnu sindroma slimniekiem. Čūlainā kolīta gadījumā $\beta$-glikāni, iespējams, samazina iekaisumu zarnās, tomēr ir nepieciešami tālāki pētījumi, kas šo efektu apstiprinātu. Kolorektāla vēža profilaksei/ārstēšanai ir veikti pārāk maz pētījumu, lai izdarītu secinājumus un sniegtu rekomendācijas par profilaksi/ārstēšanu. 